\title{
AN INVESTIGATION INTO THE SUCCESS RATES OF STUDENTS WITH NO PRIOR ACCOUNTING KNOWLEDGE IN OBTAINING A PROFESSIONAL ACCOUNTING DEGREE
}

\author{
M. Rossouw* \\ e-mail: marelir@sun.ac.za / http://orcid.org/0000-0001-6013-7031
}

\section{S. M. Brink*}

e-mail: sophiabrink@sun.ac.za / https://orcid.org/0000-0003-2716-7102

*School of Accountancy

Stellenbosch University

Stellenbosch, South Africa

\section{ABSTRACT}

Several South African universities do not require students to have completed Accounting at secondary school level in order to enrol for a degree in Accounting. At Stellenbosch University such students with no prior Accounting knowledge can still graduate and receive a Bachelor of Accounting degree (which is the first step of many towards becoming a CA (SA)) within the minimum time frame of three years given that an Accounting conversion examination is passed at the beginning of their second academic year. The literature on student performance where students have no prior Accounting knowledge focuses predominantly on first-year Accounting students. Limited studies have been expanded beyond the first academic year to investigate these students' academic career up to their final year and whether such students obtain a professional degree in Accounting. The main objective of the research reported in this article was to analyse the results of first-year conversion students (with no prior Accounting knowledge) in order to report on their success rate towards obtaining a Bachelor of Accounting degree within the minimum time of three years. In order to meet this objective, a quantitative research method was applied. It was found that half of the population was successful in obtaining their professional degree in Accounting within three years and 81 per cent of the conversion students eventually obtained their professional degree in Accounting (irrespective of time). This finding suggests that Accounting as a subject at secondary school is not necessarily essential in order to obtain a professional degree in Accounting. Receiver operating curve analyses were also done to predict optimal cut-off marks for Accounting subjects in order to obtain the desired degree within three years. These predictions, together with the actual marks obtained by the identified population, should be welcomed by prospective conversion students who now have more data available for decision-making.

Keywords: Accounting, conversion student, prior Accounting knowledge, student success. 


\section{INTRODUCTION}

Several studies have revealed that South African universities do not necessarily require students to have completed Accounting at secondary school level in order to enrol for a degree in Accounting. Many of these studies were particularly interested in such students' success rates in Accounting as a subject in their first year at university (Baard et al. 2010; Bosua and Van der Nest 2015; Papageorgiou 2017). Limited research has, however, been expanded beyond the first academic year to investigate these students' academic careers up to their final year and whether they obtain a professional degree in Accounting. ${ }^{1}$ Based on anecdotal reports from lecturers, students with no prior Accounting knowledge often approach lecturers to complain that they cannot keep up with their peers, especially since Accounting as a subject in the second and third years of study proves to be very challenging for these students. With no available statistics of previous conversion students' success rates, it is difficult to advise these students on the best course of action.

\section{PROFESSIONAL DEGREE IN ACCOUNTING AT STELLENBOSCH UNIVERSITY}

Stellenbosch University (SU) offers a Bachelor of Accounting (B. Accounting) degree. The B. Accounting degree at SU is the first step (of many) towards becoming a CA (SA). ${ }^{2}$ The admission requirements for the B. Accounting degree at SU are as follows: National Senior Certificate (NSC) average of 70 per cent; Mathematics 60 per cent and Accounting 30 per cent or Mathematics 70 per cent and Faculty of Economic and Management Sciences language admission requirements (these requirements have remained unchanged since commencement of this study) (Stellenbosch University Faculty of Economic and Management Sciences 2021). It is evident from the admission requirements that SU allows students with no prior Accounting knowledge ${ }^{4}$ to enrol for a B. Accounting degree. These students can therefore register as a B. Accounting student with all the same subjects as other B. Accounting students (who had Accounting at secondary level) with only one exception: they will be registered for an introductory Accounting module (Financial Accounting 188) versus other B. Accounting students who will be registered for a more advanced Accounting module (Financial Accounting $178^{5}$ ). When these students (with no prior Accounting knowledge) pass Financial Accounting 188 at the end of their first year at university, they must write an Accounting conversion examination (based on the course content of Financial Accounting 178) which is scheduled before classes start for the following academic year. If they pass the Accounting conversion examination, they are considered caught up with basic Accounting principles and can join their peers (who did have Accounting at secondary level) from second year B. Accounting onwards.

The Accounting conversion examination is not limited to students who did not have 
Accounting at secondary level. The conversion examination is also available to a) students who met the formal admission requirements for B. Accounting upon registration, but who registered for a different course and passed Financial Accounting 188; and b) students who did not meet the formal admission requirements for B. Accounting, but who registered for specific Bachelor of Commerce courses and passed all their subjects in year one. The study only investigated students who did not have Accounting at secondary level and who registered as a B. Accounting student (therefore with the intention of obtaining a B. Accounting degree). Henceforth these students will be referred to as "first-year conversion students".

Figure 1 depicts an intake of B. Accounting students in year 1 and shows their route towards obtaining a B. Accounting degree. This figure only considers Accounting as a subject at tertiary level and not any other subjects required to obtain a degree. The benefit of the conversion examination is that a first-year conversion student can also obtain a B. Accounting degree within three years, even without having had ample exposure to Accounting upon entering university.

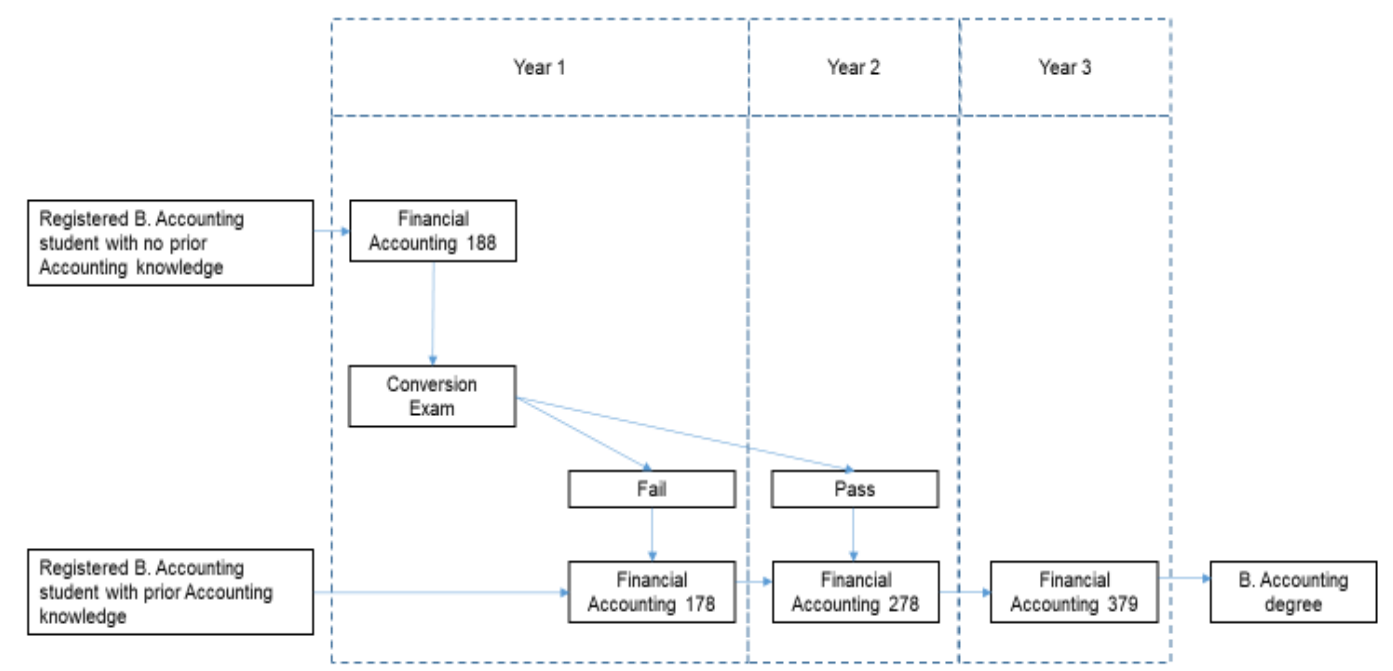

Figure 1: Route of conversion student (with no Accounting knowledge) towards obtaining a $\mathrm{B}$. Accounting degree (Source: Own figure)

\section{RESEARCH PROBLEM}

Most of the literature indicates (refer to literature review) that prior Accounting knowledge has an impact on the success of first-year Accounting students. However, the success rates of students with no prior Accounting knowledge in obtaining a professional Accounting degree at a residential university has not yet been established. The question of whether or not a lack of prior Accounting knowledge can be overcome by conversion students has also not yet been 
answered by the current body of knowledge.

\section{RESEARCH OBJECTIVE AND QUESTIONS}

The objective of this research was to analyse the results of first-year conversion students (with no prior Accounting knowledge) in order to investigate their success rate towards obtaining a B. Accounting degree. Based on the extensive literature review provided in the next section, the following research questions were developed to meet the objective:

1. What is the success rate of first-year conversion students with no prior Accounting knowledge in obtaining a professional degree in Accounting within the minimum amount of time?

2. What are the minimum marks required for Accounting as subject over the course of the professional degree in order to obtain the degree in the minimum amount of time ${ }^{6}$

\section{LITERATURE REVIEW}

An extensive literature review was conducted in order to identify what is missing from the current body of knowledge on the success rates of students with no prior Accounting knowledge in obtaining a professional Accounting degree. The literature on student performance with no prior Accounting knowledge focuses predominantly on students' results in their first academic year of studying Accounting at tertiary level.

The main objective of the study by Baard et al. $(2010,130)$ was to determine the factors that have the most significant influence on the success of first-year Accounting students at a South African university. Their research also aimed to establish a profile of successful and atrisk students. The contribution of their research was to inform admission decisions and guide the implementation of interventions for at-risk students while academically stimulating the successful students (Baard et al. 2010, 129). Baard et al. $(2010,141)$ found that one of the most important factors contributing to the success of Accounting students was whether these students had Accounting as a subject at secondary level. Papageorgiou $(2017,209)$ investigated the impact of a first-year Accounting student's profile (including age, gender and race) and preuniversity knowledge on academic performance. Papageorgiou $(2017,226)$ found a statistically significant relationship between prior Accounting knowledge and academic performance of first-year Accounting students. Similarly, Bosua and Van der Nest (2015) also investigated whether Accounting as subject at secondary level influenced performance of first-year Accounting students at tertiary level. The study also set out to determine which secondary level subject correlates more strongly with final marks in first-year Accounting at university. They 
found that Accounting as a subject at secondary level did have an influence on a student's final mark for Accounting at university and also that having Accounting as a subject at secondary level is more strongly correlated with final results in first-year Accounting at tertiary level than Mathematics or Mathematics Literacy (Bosua and Van der Nest 2015, 30).

Several international studies (Schroeder 1986; Eskew and Faley 1988; Keef and Hooper 1991; Gul and Fong 1993; Rhode and Kavanagh 1996; Rankin et al. 2003; Uyar and Güngörmüş 2011; Xiang and Gruber 2012; Aidoo-Buameh and Ayagre 2013; Duve 2016; Yusuf, Joseph and Okpe 2018) also investigated the impact of secondary school Accounting on university Accounting performance. These studies agreed that Accounting at school level is significantly associated with students' academic performance in the first-year undergraduate Accounting course.

The above research indicated that prior Accounting knowledge has a positive impact on the success of first-year Accounting students at tertiary level. The current study is however not only interested in these students' success rate in their first academic year but in their success rate up until their final year (entire academic career).

Oosthuizen and Eiselen $(2012,164)$, on the other hand, found that a student's performance in their first-year Accounting subject at university was independent of their exposure to Accounting at secondary level. However, the population of students without Accounting as a school subject in their study was considered very low in relation to students who did have this subject at school. This factor could have contributed to the insignificant relationship (Oosthuizen and Eiselen 2012, 164).

In order to eliminate the risk of finding insignificant relationships in the current study, care will be taken in the selection of the population for participation. Refer to the section entitled "Research methodology" where the period for the retrieval of data is discussed.

Smith (2009) and Smith, Case, and Walbeek (2014) investigated the effectiveness of academic development courses and programmes, especially in Commerce and in terms of graduation rates. The predominant finding regarding graduation rates, not surprisingly, was that students on development courses achieve lower graduation rates than their peers on the mainstream courses (Smith 2009, 1018; Smith et al. 2014, 635). Most of such development programmes, however, aim to assist students from disadvantaged academic and socioeconomic backgrounds. 
The first-year conversion examination under review in this study is available to any student who did not have Accounting as a subject at secondary level or students who want to switch from the course that they are currently enrolled in, to B. Accounting. The first-year conversion students, specifically those who did not have Accounting as a subject at secondary level, are therefore not necessarily from disadvantaged academic or socioeconomic backgrounds, but they do require additional assistance before continuing in the mainstream programme.

Limited research has expanded their studies on the impact of prior Accounting knowledge on university Accounting performance beyond the first academic year. Van Rensburg, Penn, and Haiden (1998) considered the performance of students with no prior Accounting exposure, not only in their first year but also in their second year of study. Van Rensburg et al. $(1998,93)$ found that having Accounting as a subject at secondary school level tended to improve a student's marks for Accounting I at tertiary level. Interestingly enough, they also found that students with no prior Accounting knowledge, who progress to write Accounting II are found to significantly outperform students with prior Accounting knowledge. Yee Lee $(1999,301)$ investigated the effects of prior Accounting knowledge on two first-year Accounting principle courses and reached a similar conclusion, stating that students with prior Accounting knowledge significantly outperformed students without high school Accounting qualification in the first, but not the second, introductory Accounting course. ${ }^{7}$

The above research indicated that prior Accounting knowledge does not impact the success of Accounting students at tertiary level beyond their first academic year. The current study is however not only interested in these students' success rates in their first two academic years, but also in their success rate in their third and final year.

Papageorgiou and Halabi (2014) investigated student performance in Accounting modules throughout the three years of a Bachelor of Accounting Science degree offered through distance education. A regression analysis was carried out on three yearly measures of performance with five independent variables (age, gender, prior Accounting knowledge, background in Mathematics and academic aptitude). Their study found that prior Accounting knowledge is significantly associated with student performance in their first year of study but not thereafter (Papageorgiou and Halabi 2014, 211). In noting the limitations of their study, Papageorgiou 
and Halabi $(2014,211)$ state that because only one university (and more specifically a distance learning university) was included in the study the generalisability of the results to other institutions is limited.

Only one study could be found that considered the entire three-year period of a degree in Accounting. The study recommended that future research could be extended to other tertiary education institution providers in South Africa (other than a distance learning university) (Papageorgiou and Halabi 2014, 211). The current study will cover the same three-year period of a degree in Accounting, but the study will be conducted at a residential university (versus distance learning university).

A summary of the existing literature follows: Most of the existing literature focuses on the impact of no prior Accounting knowledge on students' performance in Accounting in their first academic year at university. Some of these studies focused only on Bachelor of Commerce students (non-CA route) (Baard et al. 2010, 133; Oosthuizen and Eiselen 2012, 162) or only on Bachelor of Accounting students (CA route) (Papageorgiou and Halabi 2014, 211), while other studies included both Bachelor of Commerce students (non-CA route) and Bachelor of Accounting students (CA route) (Papageorgiou 2017, 214; Bosua and Van der Nest 2015, 17). Only two studies expanded their research to include second-year Accounting students' performance and only one study investigated Accounting students' performance over the course of the three-year degree. The latter study was conducted on a distance learning programme and not at a residential university (as was the case in this study).

It is clear from the literature review that there is a gap in the existing body of knowledge on the success rates of students with no prior Accounting knowledge in obtaining a professional Accounting degree at a residential university, hence students' success in Accounting beyond their first (and second) academic years.

\section{RESEARCH METHODOLOGY}

This research study used a quantitative research method, focusing on B. Accounting conversion students' success rates throughout their B. Accounting degree (a minimum three-year period) at SU's Faculty of Economic and Management Sciences. In order to answer the research questions the relevant data were collected from the university's central computer system. The research project was assessed by two ethics screening committees and both committees deemed this study to be at a low risk. Research was conducted according to approved research protocol. 
In order to determine which time period should be selected for the retrieval of data, we referred to studies which also considered the success rates of students with no prior Accounting knowledge. The methodologies of previous studies (on the subject matter) covered various time periods. Data were retrieved for one year (Baard et al. 2010; Oosthuizen and Eiselen 2012), two years (Bosua and Van der Nest 2015), three years (Van Rensburg et al. 1998) and five years (Papageorgiou 2017). In order to ensure that a comprehensive study would be done, it was decided, based on Papageorgiou's (2017) research, to analyse the data covering a period of five years as well. This would eliminate the risk of a too small population that might cause insignificant relationships as was the case in Oosthuizen and Eiselen (2012).

Only students who had registered for B. Accounting upon entering SU (therefore, students who intended to obtain a professional degree in Accounting) and who did not have Accounting as a subject at secondary level were considered for analysis in this study. This study extracted data for students who registered for B. Accounting in 2012 to 2016, therefore attempting the conversion examination in 2013 to 2017. This specific time frame would ensure that data needed for analysis was available at the time of this study (a student writing the conversion examination in 2017 can obtain a professional degree in Accounting at the end of 2018).

The time frame for retrieval of data therefore started at the end of a first-year conversion student's first academic year with their Financial Accounting 188 mark. A student's mark for the conversion examination follows at the beginning of their second academic year. If a student was successful in the conversion examination, their mark for Financial Accounting 278 was retrieved at the end of their second academic year and followed by their mark for Financial Accounting 379 at the end of their third academic year (also refer to Figure 1). The marks used in this study were those obtained for a student's first attempt of the module. If a student registered for B. Accounting and did not continue to write the conversion examination, they were not included for analysis irrespective of their mark for Financial Accounting 188. If a student decided to change from B. Accounting to another course or discontinued their studies after having written the conversion examination, their results for the assessments that they had completed were analysed. This decision was made on the assumption that students who wrote the conversion examination intended to obtain a B. Accounting degree and such results should be used to predict success rates and minimum marks for prospective students.

For purposes of determining the success rate in this study, a successful student was defined as a student who registered for B. Accounting without any prior Accounting knowledge, who passed a) Financial Accounting 188, b) the conversion examination, c) Financial Accounting 278 and d) Financial Accounting 379 (by obtaining a minimum mark of 50 per cent for each of 
these assessments), therefore being able to obtain a B. Accounting degree within three years (if they also pass their other subjects). An unsuccessful student was defined as a student who failed one (or more) of these assessments which resulted in their failing to obtain a B. Accounting degree within three years; or a student who passed some of these assessments but decided not to continue with their studies or converted to another degree.

\section{STATISTICAL ANALYSIS}

The data were processed and analysed using the Statistica application (version 13.4.0.14) and the R package "pROC" version 1.15.3. Analysis of variance (ANOVA) tests were done to compare marks between students who did obtain their B. Accounting degree within three years and those who did not. A 5 per cent significance level was applied $(p=0.05)$. Receiver operating curve (ROC) analyses were used to establish cut-off points. Sensitivity and specificity ratios were determined.

\section{RESEARCH RESULTS AND FINDINGS}

Data were retrieved for the five-year period from 2013 to 2017 and resulted in 118 data items. These students all registered for B. Accounting, passed their Financial Accounting 188 module (this module being their first introduction to Accounting as subject) and attempted the conversion examination. Conversion student demographics for the five years under review showed that most of these students are white (86\%), male (51\%), and have English as their home language $(76 \%)$. The results were not analysed for conversion student demographics seeing as this does not contribute to the research questions.

\section{Research question 1: What is the success rate of first-year conversion students with no prior Accounting knowledge in obtaining a professional degree in Accounting within the minimum amount of time?}

For the five years under review, 78 per cent (92/118) of students passed the conversion examination and therefore gained access to Financial Accounting 278. Of these students, 77 per cent (71/92) passed Financial Accounting 278 and 85 per cent (60/71) went on and passed Financial Accounting 379. Of the 60 students who passed Financial Accounting 379, 59 obtained their B. Accounting degree within three years. Only one student passed all his/her Accounting modules throughout his/her undergraduate studies but failed another subject (that is not Accounting), consequently failing to obtain a degree within three years. Therefore, in total, 59 of the 118 students $(50 \%)$ who initially wrote the conversion examination obtained their B. Accounting degree within the minimum period of three years. See Table 1 for a 
summary of the results for the five years under review.

Table 1: Summary of the number of students for the five years under review

\begin{tabular}{|l|c|c|c|c|c|c|}
\hline & $\mathbf{2 0 1 3}$ & $\mathbf{2 0 1 4}$ & $\mathbf{2 0 1 5}$ & $\mathbf{2 0 1 6}$ & $\mathbf{2 0 1 7}$ & Total \\
\hline $\begin{array}{l}\text { Number of students who wrote the } \\
\text { conversion examination }\end{array}$ & 18 & 13 & 24 & 32 & 31 & 118 \\
\hline $\begin{array}{l}\text { Number of students who passed the } \\
\text { conversion examination and gained access } \\
\text { to Financial Accounting 278 }\end{array}$ & 13 & 12 & 15 & 28 & 24 & 92 \\
\hline $\begin{array}{l}\text { Number of students who passed Financial } \\
\text { Accounting 278 }\end{array}$ & 11 & 10 & 11 & 20 & 19 & 71 \\
\hline $\begin{array}{l}\text { Number of students who passed Financial } \\
\text { Accounting 379 }\end{array}$ & 9 & 8 & 10 & 17 & 16 & 60 \\
\hline $\begin{array}{l}\text { Number of students who obtained their B. } \\
\text { Accounting degree within the minimum time } \\
\text { frame (3 years) }\end{array}$ & 9 & 8 & 9 & 17 & 16 & 59 \\
\hline
\end{tabular}

The academic careers of the remaining 59 students (who did not obtain their B. Accounting degree within three years) were tracked up until the date of the study in order to ensure comprehensiveness in reporting the findings. Most of these students, that is 36 of the 59, went on to obtain their B. Accounting degree even though it took them more than three years to do so. See Table 2 for a summary of the first-year conversion students, from 2013 to 2017, with their graduation status at the time of this study.

Eventually, 81 per cent (95/118) of the students who had no prior Accounting knowledge were able to obtain a professional Accounting degree (irrespective of how long it took) and therefore had the opportunity to become a CA (SA). The researchers consider this a significant portion of the total population.

Our finding suggests that Accounting as subject at secondary school is not necessarily important in order to obtain a professional degree in Accounting. This finding, for research done at a residential university, supports the findings of Papageorgiou and Halabi (2014) (whose research was conducted at a distance learning university). The finding also endorses the admission requirements of SU where Accounting is not a prerequisite for registering as a $\mathrm{B}$. Accounting student.

Table 2: Summary of first-year conversion students and their graduation status at the time of this study

\begin{tabular}{|l|c|c|}
\hline & Number & Percentage \\
\hline Students who obtained their B. Accounting degree within three years & 59 & 50 \\
\hline Students who obtained a B. Accounting degree in more than three years & 36 & 31 \\
\hline Students who obtained a B. Commerce degree & 9 & 8 \\
\hline Students who discontinued their studies & 10 & 8 \\
\hline Students who had not yet obtained any degree at the time of this study & $\underline{4}$ & $\underline{3}$ \\
\hline Total population of first-year conversion students & 118 & 100 \\
\hline
\end{tabular}




\section{Research question 2: What are the minimum marks required for Accounting as a subject over the course of the professional degree in order to obtain the degree in the minimum amount of time?}

It was expected that students who did obtain their degree within three years would have better results for their subjects than those who did not. ANOVA tests were done for all four assessments $^{8}$ to determine whether the difference in marks obtained were considered significant. The results are summarised in Table 3 . It is clear from the summary of the results that the difference in marks for all assessments was significant. The 59 students' marks, that is those who obtained their B. Accounting degree within three years, were significantly better than those who did not obtain their degree within three years with $p<0.01$ for all assessments. These students obtained an average of 75 per cent for Financial Accounting 188, 64 per cent for the conversion examination, 60 per cent for Financial Accounting 278 and 61 per cent for Financial Accounting 379.

Table 3: Summary of results, per assessment, for students who obtained their B. Accounting degree within three years versus those who did not

\begin{tabular}{|c|c|c|c|c|c|}
\hline Subject & $\begin{array}{c}\text { Number of } \\
\text { participants }\end{array}$ & Mean (\%) & $\begin{array}{l}\text { Standard } \\
\text { deviation }\end{array}$ & $\mathbf{F}$ & $\begin{array}{c}F \\
\text { ( } p \text { value) }\end{array}$ \\
\hline Financial Accounting 188 & & & & \multirow{3}{*}{31.73} & \multirow{3}{*}{$<0.01$} \\
\hline B. Accounting in three years & 59 & 75 & 11.7 & & \\
\hline B. Accounting not in three years & 59 & 63 & 10.4 & & \\
\hline \multicolumn{4}{|l|}{ Conversion examination } & \multirow{3}{*}{67.59} & \multirow{3}{*}{$<0.01$} \\
\hline B. Accounting in three years & 59 & 64 & 10.1 & & \\
\hline B. Accounting not in three years & 59 & 47 & 12.3 & & \\
\hline \multicolumn{4}{|l|}{ Financial Accounting 278} & \multirow{3}{*}{50.06} & \multirow{3}{*}{$<0.01$} \\
\hline B. Accounting in three years & 59 & 60 & 11.2 & & \\
\hline B. Accounting not in three years & 28 & 43 & 9.7 & & \\
\hline \multicolumn{4}{|l|}{ Financial Accounting 379} & \multirow{3}{*}{59.15} & \multirow{3}{*}{$<0.01$} \\
\hline B. Accounting in three years & 59 & 61 & 9.5 & & \\
\hline B. Accounting not in three years & 24 & 41 & 13.7 & & \\
\hline
\end{tabular}

ROC analyses were done for all four Accounting assessments to predict optimal cut-off marks in order to obtain a B. Accounting degree within three years. The four ROC analyses were also used to determine the area under the curve (AUC), which is an indicator of the overall accuracy of the predictions made. The ROC analyses and AUCs are summarised in Table 4.

The ROC and AUC results can be interpreted as follows: if a student (with no prior Accounting knowledge) obtains 67.5 per cent for Financial Accounting 188, they should obtain their degree within three years. This finding is considered 77 per cent accurate (with AUC reported as 0.77 ). The sensitivity of 0.71 indicates that, in 71 per cent of the cases reported, students who did achieve 67.5 per cent (or more), were successful in obtaining their degree 
within three years. The specificity of 0.69 indicates that 69 per cent of the cases reported, where students who obtained less than 67.5 per cent, were correct in predicting that they would not obtain their degree within three years. The interpretations for the conversion examination, Financial Accounting 278 and Financial Accounting 379 follow the same explanation as for Financial Accounting 188.

Table 4: Receiver operating curve analyses with area under curve for four Accounting modules' assessments

\begin{tabular}{|l|c|c|c|c|c|}
\hline & Cases reported & ROC & Sensitivity & Specificity & AUC \\
\hline Financial Accounting 188 & 118 & 67.5 & 0.71 & 0.69 & 0.77 \\
\hline Conversion examination & 118 & 54.5 & 0.88 & 0.78 & 0.87 \\
\hline Financial Accounting 278 & 87 & 50.5 & 0.73 & 0.82 & 0.87 \\
\hline Financial Accounting 379 & 83 & 52.5 & 0.80 & 0.92 & 0.92 \\
\hline
\end{tabular}

The results from the ROC analyses, for all four assessments, are lower than the actual averages reported for the 59 students (refer to "Mean" percentages in Table 3). Prospective students are advised to use both the actual results reported (Table 3) and the ROC analyses (Table 4) as guidelines when seeking to predict their success in obtaining a degree within three years.

\section{SUMMARY, CONCLUSION AND RECOMMENDATIONS}

Accounting as a subject at secondary school level is not a prerequisite for enrolment in a professional degree in Accounting (which is the first step of many towards becoming a CA (SA)) at SU. Many studies have sought to determine students', with no prior Accounting knowledge, success in Accounting at tertiary level. However, these studies focused predominantly on students' results in Accounting in their first academic year. A gap was identified in the existing literature to determine the success rate of such students, with no prior Accounting knowledge upon entering a residential university, in obtaining a professional degree in Accounting within the minimum time of three years. It was found that 50 per cent of first-year conversion students were successful in obtaining their B. Accounting degree within three years. Eventually, however, 81 per cent of the population did obtain a B. Accounting degree (up until the date of the study), irrespective of how long it took. This suggests that Accounting as a subject at secondary level is not necessarily essential in order to obtain a professional degree in Accounting. This study proves that the current admission requirements at SU (which allow a student to register for B. Accounting without having Accounting at secondary level) are considered appropriate. The results of this study imply that student counsellors and student advisers could highlight the fact that having Accounting at secondary level is not a prerequisite for success in the B. Accounting degree programme when advising 
secondary school students and prospective conversion students. The contributing factor of this finding is that the pool of students with no prior Accounting knowledge who wish to enrol for the B. Accounting programme is possibly widened with the actual results reported for the five years from 2013-2017.

It was also determined, with the help of ROC analyses, that minimum marks of 67.5 per cent for Financial Accounting 188, 54.5 per cent for the conversion examination; 50.5 per cent for Financial Accounting 278 and 52.5 per cent for Financial Accounting 379 would most likely ensure graduation within three years of first registration for the professional degree. These optimal cut-off marks for Accounting subjects paint a clear picture to students what is expected of them and can be applied for student goal setting purposes. This might also reduce the risk of conversion students failing or of wasting additional year(s) of studying. The distinguishing features of this current study are that it:

- $\quad$ was conducted at a residential university (compared to distance learning institutions);

- $\quad$ selected a time period of five years to retrieve data (compared to most studies on the same topic who considered data from a smaller time frame);

- $\quad$ included the entire B. Accounting undergraduate time period of three years (compared to most studies on the same topic that only considered the first year).

It is fair to conclude that this study improved on previous studies in various ways.

This article only investigated the success rates of first-year B. Accounting conversion students. SU also offers students who graduated with a Bachelor of Commerce (B. Commerce) in Management Accounting or a B. Commerce in Financial Accounting the opportunity to convert to a B. Accounting by completing a conversion year. The conversion year entails the following: after obtaining one of the above-mentioned degrees these students can register as special students (non-degree purposes) for the four main B. Accounting subjects ${ }^{9}$ and Mercantile Law ${ }^{10}$ (Daniels 2018). The purpose and the reason why most students decide on this conversion year is to meet the B. Accounting Honours admission requirements, which puts them on course to eventually become a CA (SA). It is therefore possible that a student (with no prior Accounting knowledge and who initially registered for B. Accounting) who was unsuccessful in the conversion examination at the beginning of their second academic career can still obtain a B. Accounting degree if they decide on this alternative course of action. A recommendation for further research is to investigate the success rates of these third-year B. Accounting conversion students.

The results of B. Accounting first-year students were only analysed for a fixed amount of 
time (5 years) and only at one South African university. A further limitation is that this study only took into consideration students' marks for Accounting modules in their academic career. Other subjects' marks needed in order to obtain a degree were not considered given the specific focus on Accounting. Therefore, other subjects were only considered for their contribution towards obtaining a degree, or not. Even though the study was conducted in South African (where the problem was identified) it is believed that the findings can also be applied internationally for comparative study purposes should a similar study be done internationally.

Further research is suggested to investigate other factors that have an impact on the success rate of students with no prior Accounting knowledge in obtaining a professional degree in Accounting.

\section{NOTES}

1. A professional degree in Accounting, for purposes of this study, means that the programme is accredited by the South African Institute of Chartered Accountants (SAICA) and in obtaining this degree a student is on course to becoming a CA (SA).

2. Becoming a CA (SA) entails the following: Obtaining a B. Accounting degree (three years), obtaining a B. Accounting Honours degree (one year), completing a three-year traineeship programme with a registered auditing firm or with another registered training office and passing the two Qualifying Examinations, namely the Initial Test of Competence (ITC) and the Assessment of Professional Competence (APC).

3. The school accounting curriculum cover the following topics in Grade 12: Companies (including financial statements, analysis and interpretation), ethics, fixed assets, close corporation, internal control, inventory systems, reconciliations, value added tax, cost accounting and budgeting (Department Basic Education Republic of South Africa 2020).

4. In this study, "no prior Accounting knowledge" refers to a student who did not have Accounting as a subject at secondary school level.

5. Financial Accounting 188 covers most of the major topics included in the school curriculum and additional topics. Financial Accounting 188 covers the theoretical principles of International Financial Reporting Standards, accounting systems and the preparation and presentation of financial statements for different enterprises. Financial Accounting 178 covers all the major topics included in Financial Accounting 188 on a more advanced level and additional topics. Financial Accounting 178 covers the accounting cycle; conceptual framework for financial reporting, value added tax, selected International Financial Reporting Standards, accounting treatment of consignments, preparation and presentation of financial statements of companies; and introduction to group statements (Stellenbosch University Faculty of Economic and Management Sciences 2020, 245-246).

6. The results of the following four assessments were considered: Financial Accounting 188, Conversion examination, Financial Accounting 278 and Financial Accounting 379.

7. This study can be regarded as an investigation into student performance beyond the first academic year as the completion of Accounting I was a prerequisite for Accounting II (Yee Lee 1999, 301).

8. Financial Accounting 188, Conversion examination, Financial Accounting 278 and Financial Accounting 379

9. Financial Accounting, Management Accounting, Auditing and Taxation

10. A B. Accounting second-year module that is not included in the B. Commerce programme. 


\section{REFERENCES}

Aidoo-Buameh, J. and P. Ayagre. 2013. "The Effect of Entry Grades on Academic Performance of University Accounting Students: A case of Undergraduates of Central University College.” Research Journal of Finance and Accounting 4(7): 198-207.

Baard, R. S., L. P. Steenkamp, B. L. Frick, and M. Kidd. 2010. "Factors influencing success in firstyear Accounting at a South African university: The profile of a successful first-year Accounting student." South African Journal of Accounting Research 24(1): 129-147.

Bosua, W. S. and D. P. Van der Nest. 2015. "The effect of prior knowledge and academic performance on success in first-year university Accounting.” Journal for New Generation Sciences 13(3): 1733.

Daniels, N. 2018. Email to author. (ndaniels@sun.ac.za). October 2018. RE: Nie-graaddoeleindes Oorbrugging.

Department Basic Education Republic of South Africa. 2020. "Curriculum and Assessment Policy Statement Grades 10-12 Accounting." https://www.education.gov.za/Curriculum/Curriculum AssessmentPolicyStatements(CAPS)/CAPSFET.aspx (Accessed 21 April 2020).

Duve, M. 2016. "Non-accounting Students' Academic Performance and Introductory Financial Accounting Course: A Case of Great Zimbabwe University." Journal of Business Administration and Education 8(2): 36-62.

Eskew, R. K. and R. H. Faley. 1988. "Some determinants of student performance in the first Collegelevel Financial Accounting." The Accounting Review LXVII(1): 137-147.

Gul, F. A. and S. C. C. Fong. 1993. "Predicting success for introductory Accounting students: Some further Hong Kong evidence." Accounting Education 2(1): 33-42.

Keef, S. and K. C. Hooper. 1991. "Prior Accounting education and performance in a first-level university course in New Zealand." Accounting and Finance 31: 85-92.

Oosthuizen, A. and R. Eiselen. 2012. "Factors associated with success in first-year Accounting after the implementation of the National Senior Certificate." Acta Academica 44(3): 156-174.

Papageorgiou, E. 2017. "Accounting student's profile versus academic performance: A five-year analysis." South African Journal of Higher Education 31(3): 209-229.

Papageorgiou, K. and A. K. Halabi. 2014. "Factors contributing toward student performance in a distance education Accounting degree." Meditari Accounting Research 22(2): 211-223.

Rankin, M., Silvester, M. Vallely, and A. Wyatt. 2003. "An analysis of the implication of diversity for students' first level Accounting performance." Accounting and Finance 43: 365-393.

Rhode, F. H. and M. Kavanagh. 1996. "Performance in first-year university Accounting: Quantifying the advantage of secondary school Accounting." Accounting and Finance 36: 275-285.

Schroeder, N. W. 1986. "Previous Accounting education and college-level Accounting exam performance." Issues in Accounting Education 1(1): 37-47.

Smith, L. C. 2009. "Measuring the success of an academic development programme: A statistical analysis." South African Journal of Higher Education 23(5): 1009-1025.

Smith, L. C., J. M. Case, and C. Walbeek. 2014. "Assessing the effectiveness of academic development programmes: A statistical analysis of graduation rates across three programmes." South African Journal of Higher Education 28(2): 624-638.

Stellenbosch University Faculty of Economic and Management Sciences. 2020. "Academic Programmes and Faculty Information." http:/www.sun.ac.za/english/Documents/Yearbooks/ Current/EconomicAndManagementSciences.pdf (Accessed 28 April 2020).

Stellenbosch University Faculty of Economic and Management Sciences. 2021. "Undergraduate programmes for 2021/2022." http://www.sun.ac.za/english/faculty/economy/Documents/ FACULTY_BROCHURE_2021-22_small\%20version.pdf (Accessed 14 April 2021).

Uyar, A. and A. H. Güngörmüş. 2011. "Factors associated with student performance in financial 
Accounting courses." European Journal of Economics and Political Studies 4(2): 139-153.

Van Rensburg, P., G. Penn, and M. Haiden. 1998. "A note on the effect of secondary school Accounting study on university Accounting performance." South African Journal of Accounting Research 12(1): 93-98.

Xiang, M. and R. Gruber. 2012. "Student Performance in their First Postsecondary Accounting Course: Does High School Accounting Matter?" Advances in Accounting Education 13: 297-311.

Yee Lee, D. S. 1999. "Strength in high school Accounting qualification and student performance in university-level introductory Accounting courses in Hong Kong." Journal of Education and Business 74(5): 301-306.

Yusuf, I., Joseph, S. and Okpe J.U. 2018. Prior knowledge and academic performance in first year accounting course. International Journal of Higher Education and Sustainability 2(1): 1-16. 